\title{
Efficiency of five biosolids to supply nitrogen and phosphorus to ryegrass
}

\author{
Rodrigo Studart Corrêa ${ }^{(1)}$ \\ (1)Universidade de Brasília, Caixa Postal 10.814, CEP 70324-980 Brasília, DF, Brazil. E-mail: rodmanga@yahoo.com.br
}

\begin{abstract}
Biosolids have been considered satisfactory to supply crops and plant nutrients. The ideal biosolids application rate should result in high crop yields and nutrient uptake, and leave low concentrations of nutrients in soils to avoid environmental problems. The objective of this study was to estimate the capacity of five biosolids to supply $\mathrm{N}$ and $\mathrm{P}$ to ryegrass (Lolium perenne) after a single application of either fertilizers or biosolids to a Spodosol and an Oxisol. Results showed that $6 \%-36 \%$ of N and $3 \%-7 \%$ of P applied as biosolids were recovered in plants grown on the Spodosol, while the range on the Oxisol was $26 \%-75 \%$ for $\mathrm{N}$ and $1.2 \%-3.7 \%$ for phosphorus. Biosolids' efficiency on supplying N and P to plants was similar to fertilizer on the Spodosol, but on the Oxisol it refrained to $65 \%-67 \%$ fertilizer's efficiency. After a single application of biosolids followed by six consecutive harvests, $25 \%-94 \%$ of the $\mathrm{N}$ and $93 \%-99 \%$ of the $\mathrm{P}$ were not used by plants and remain in the soils.
\end{abstract}

Index terms: Lolium perenne, sewage sludge, nutrient efficiency.

\section{Eficiência de cinco biossólidos em suprir nitrogênio e fósforo para azevém}

\begin{abstract}
Resumo - Biossólidos têm sido considerados eficientes em suprir nutrientes às culturas. A dose ideal deve resultar em alta produtividade e absorção de nutrientes pelas plantas e em baixas concentrações de elementos químicos nos solos, a fim de se evitar problemas ambientais. O objetivo deste trabalho foi estimar a capacidade de cinco biossólidos em suprir N e P para o azevém (Lolium perenne) após a aplicação de dose única de fertilizantes ou de biossólidos num Espodossolo e num Latossolo. Os resultados mostram que entre 6\%-36\% do $\mathrm{N}$ e 3\%-7\% do $\mathrm{P}$ aplicado como biossólidos foram recuperados nas plantas cultivadas no Espodossolo, ao passo que no Latossolo os valores variaram de 26\%-75\% quanto ao $\mathrm{N} \mathrm{e} \mathrm{1,2 \% -3,7 \%} \mathrm{quanto} \mathrm{ao} \mathrm{fósforo.} \mathrm{A} \mathrm{eficiência}$ de biossólidos em suprir $\mathrm{N}$ e $\mathrm{P}$ para as plantas foi similar ao fertilizante no Espodossolo, mas no Latossolo alcançou o limite de 65\%-67\%, medida com a aplicação de fertilizantes. Após uma única aplicação de biossólidos seguida de seis colheitas consecutivas, $25 \%-94 \%$ do $\mathrm{N}$ e $93 \%-99 \%$ do P adicionados não são utilizados pelas plantas e permanecem nos solos.
\end{abstract}

Termos para indexação: Lolium perenne, lodo de esgoto, eficiência de nutrientes.

\section{Introduction}

The concept of adding organic matter, nitrogen $(\mathrm{N})$, and phosphorus $(\mathrm{P})$ back into the natural cycle forms the basis of sewage sludge (biosolids) land application (Frank, 1998). A wide spectrum of biosolids has been produced and reported to satisfactorily yield crops and supply plant nutrients.

The USEPA 40 CFR Part 503 (USEPA, 1995) and other environmental agencies worldwide support the use of biosolids on lands as long as they are applied at agronomic rates based on crop $\mathrm{N}$ requirements. Nitrogen agronomic rate is defined as the amount of biosolids applied to achieve high crop yield and nutrient uptake, and leave in the soil low nutrient concentrations to avoid environmental problems. This requires data on biosolids nutrient content, mineralization rate, and its equivalence to fertilizers (Barbarick \& Ippolito, 2000).

Although positive yield responses to increasing biosolids application rates have been reported for various crops and forest plantations (Cameron et al., 1996), the capacity of sewage materials to supply nutrients has been difficult to predict. It depends on various factors other than the sludge itself, such as inherent soil characteristics, crop nutrient demand, and biosolids placement and timing (Oberle \& Keeney, 1994). A traditional method in determining source nutrient availability involves measuring plant uptake, a function of the availability of soil nutrients and plant growth rate (O'Brien, 1998). Nutrient content in harvested materials provides an estimate of nutrient supply from a given source (Havilah et al., 1996). Such an evaluation is more reliable when 
more than one harvest is considered (Nooman \& Füleky, 1995).

Nutrient use efficiency has been commonly defined as the amount of dry matter produced per unit of an element supplied, and it is often more important than competition for light in determining the success of a plant to survive and thrive in the first stages of development (Vaz \& Gonçalves, 2002). Another concept involves determining the ratio of plant nutrient uptake (dry matter weight $\mathrm{x}$ plant nutrient concentration) to supplied amount. This latter concept is an indication of plant internal nutrient efficiency (Bolland, 1997) and it is widely used to compare species of contrasting growth or the availability of nutrients from different sources ( $\mathrm{O}$ 'Brien, 1998).

The objective of this study was to estimate the capacity of five biosolids to supply $\mathrm{N}$ and $\mathrm{P}$ to ryegrass (Lolium perenne) after a single application of either fertilizers or biosolids to a Spodosol and an Oxisol soil.

\section{Material and Methods}

A $500 \mathrm{~kg}$ sample of freshly tertiary sewage sludge was collected from Bendigo's treatment plant, Australia, in September 1998 and analyzed in triplicate for gravimetric water content $\left(105^{\circ} \mathrm{C}\right.$ for 48 hours $)$ and bulk density (BD). Fresh sewage biosolids (Table 1) presenting $878 \mathrm{~g} \mathrm{~kg}^{-1}$ moisture, $1.2 \mathrm{Mg} \mathrm{m}^{-3}$ of $\mathrm{BD}$, and $\mathrm{C} / \mathrm{N}$ ratio of 6.2 were mixed with hardwood sawdust (96 g kg-1 moisture; $0.3 \mathrm{Mg} \mathrm{m}^{-3}$ of $\mathrm{BD}$; and $\mathrm{C} / \mathrm{N}$ ratio of 668 ) and woodchips (bulk agent) to achieve a $\mathrm{C} / \mathrm{N}$ ratio of 25:1. Three $450 \mathrm{~L}$ composting piles were pitched on a sheltered cement pavement, run at $35^{\circ} \mathrm{C}-65^{\circ} \mathrm{C}$ for 34 days, let to mature for another 60 days and passed through a 2-mm sieve. Lime treatment employed $\mathrm{CaO}$ at $30 \%$ rate to fresh biosolids, on a dry weight basis (weight/weight). Heat drying was performed on the fresh biosolids in a furnace at $250^{\circ} \mathrm{C}$ until constant weight. The heat-dried biosolid was ground and also passed through a 2-mm sieve. For solar irradiation process, three $10 \mathrm{~kg}$ fresh biosolids samples were stored in freely draining plastic bowls under transparent plastic-covers for 14 days, with daily temperatures ranging from $12.8^{\circ} \mathrm{C}$ to $26.5^{\circ} \mathrm{C}$.

The stabilization criteria proposed by the USEPA (1995) were achieved in all the employed processes. All biosolids were analyzed, in triplicate, for total $\mathrm{N}$ and total C (dry combustion method), mineral $\mathrm{N}\left(\mathrm{NH}_{4}{ }^{+}-\mathrm{N}+\right.$ $\mathrm{NO}_{3}{ }^{-}-\mathrm{N}$ by Kjeldahl steam distillation method), total $\mathrm{P}$ $\left(\mathrm{HNO}_{3}+\mathrm{H}_{2} \mathrm{SO}_{4}\right.$ digestion followed by molybdatevanadate color development) and available P (Bray 1) (Table 1).

Two contrasting soils were utilized: a sandy "Espodossolo Cárbico Órtico" and a clayey "Latossolo Vermelho perférrico" (Embrapa, 1999). A $200 \mathrm{~kg}$ sample of each soil was collected from native areas in Victoria, Australia, and allowed to air dry for two weeks, then passed through a 4-mm sieve. Soil characteristics are presented in Table 2.

A factorial scheme experiment was chosen for plant test ( 2 soils $\times 5$ biosolids $\times 3$ replication $=30$ pots $)$ as an experiment on this scale can be better controlled. In a glasshouse experiment, $1.8 \mathrm{~kg}$ soil samples were amended in triplicate at an equivalent biosolid rate of 1.0 dry $\mathrm{Mg} \mathrm{ha}^{-1}$ (Table 3 ) and placed in $2 \mathrm{~L}$ pots, wetted with deionized water to their field capacity and allowed to rest on saucers for a week at $25^{\circ} \mathrm{C}$ glasshouse environment before sowing. Three samples of both unamended Spodosol and Oxisol (six pots) were used as control soils. Three samples of Spodosol and Oxisol

Table 1. Some characteristics of stabilized biosolids ${ }^{(1)}$.

\begin{tabular}{|c|c|c|c|c|c|}
\hline Property & $\begin{array}{c}\text { Fresh } \\
\text { biosolids }\end{array}$ & $\begin{array}{l}\text { Composted } \\
\text { biosolids }\end{array}$ & $\begin{array}{l}30 \%-\mathrm{CaO} \\
\text { biosolids }\end{array}$ & $\begin{array}{c}250^{\circ} \mathrm{C} \text {-dried } \\
\text { biosolids }\end{array}$ & $\begin{array}{c}\text { Solar-irradiated } \\
\text { biosolids }\end{array}$ \\
\hline & \multicolumn{5}{|c|}{ Dry weight basis } \\
\hline Total N $\left(\mathrm{g} \mathrm{kg}^{-1}\right)$ & $65.1 \mathrm{a}$ & $15.9 b$ & $40.1 \mathrm{c}$ & $64.8 \mathrm{a}$ & $65.3 \mathrm{a}$ \\
\hline Total $\mathrm{P}\left(\mathrm{g} \mathrm{kg}^{-1}\right)$ & $72.1 \mathrm{a}$ & $24.2 b$ & $50.6 \mathrm{c}$ & $72.5 \mathrm{a}$ & $72.6 a$ \\
\hline Mineral $\mathrm{N}\left(\mathrm{mg} \mathrm{kg}^{-1}\right)$ & $624 a$ & $277 \mathrm{~b}$ & $93.8 \mathrm{c}$ & $356 \mathrm{~d}$ & $803 \mathrm{e}$ \\
\hline Available $\mathrm{P}\left(\mathrm{mg} \mathrm{kg}^{-1}\right)$ & $268 \mathrm{a}$ & $377 b$ & $11.9 \mathrm{c}$ & $678 \mathrm{~d}$ & $199 \mathrm{e}$ \\
\hline Bulk density $\left(\mathrm{Mg} \mathrm{m}^{-3}\right)$ & $1.2 \mathrm{a}$ & $0.4 \mathrm{~b}$ & $1.4 \mathrm{c}$ & $0.6 \mathrm{~d}$ & $1.3 \mathrm{ac}$ \\
\hline Gravimetric water $\left(\mathrm{g} \mathrm{kg}^{-1}\right)$ & \multicolumn{5}{|c|}{ Wet weight basis } \\
\hline
\end{tabular}

${ }^{(1)}$ Means with same letter within rows are not statistically different by the Tukey test at $5 \%$ probability level. 
(six pots) were applied with chemical fertilizers to be used as a chemical reference for the experiment. Chemical sources were applied to soils at rates of $64 \mathrm{mg} \mathrm{kg}^{-1} \mathrm{~N}, 142 \mathrm{mg} \mathrm{kg}^{-1} \mathrm{P}, 78 \mathrm{mg} \mathrm{kg}^{-1} \mathrm{~K}, 62 \mathrm{mg} \mathrm{kg}^{-1} \mathrm{Ca}$ and $58 \mathrm{mg} \mathrm{kg}^{-1} \mathrm{Mg}$. A commercial formulation containing $120 \mathrm{~g} \mathrm{~kg}^{-1}$ of $\mathrm{FeSO}_{4}, 25 \mathrm{~g} \mathrm{~kg}^{-1}$ of $\mathrm{MnSO}_{4}, 10 \mathrm{~g} \mathrm{~kg}^{-1}$ of $\mathrm{ZnSO}_{4}, 5 \mathrm{~g} \mathrm{~kg}^{-1}$ of $\mathrm{CuSO}_{4}, 1 \mathrm{~g} \mathrm{~kg}^{-1}$ of $\mathrm{Na}_{2} \mathrm{BO}_{3}$ and $1 \mathrm{~g} \mathrm{~kg}^{-1}$ of $\mathrm{Na}_{2} \mathrm{MoO}_{4}$ was also applied at $1,000 \mathrm{mg} \mathrm{kg}^{-1}$ soil rate. Pots containing control soils and fertilized soils were placed among the thirty biosolids-amended soil pots and treated alike. Biosolids and fertilizers were applied only once, prior to planting. Soil samples from the 42 pots were analyzed for total $\mathrm{N}$ and $\mathrm{P}$, mineral $\mathrm{N}$, and available $\mathrm{P}$ at the beginning and at the end of the plant trial using the same analytical methods described for the biosolids.

Pots were sown in December 1998 (summer) with ten seeds of ryegrass (Lolium perenne) at $0.5 \mathrm{~cm}$ depth and $10-20 \mathrm{~mL}$ of distilled water were applied daily to meet plant requirements. Two weeks after sowing, pots were thinned to five plants per pot, leaving the most uniform plants. Pots were randomized weekly and plants were allowed to regrow to be harvested at eight-week intervals, until responses to biosolids and fertilizers equaled yields from unamended control soils. Plant materials from every harvest were oven-dried $\left(70^{\circ} \mathrm{C}\right.$ for 72 hours) and dry matter was weighted to account yield and cumulative yield from each treatment before elemental analysis.

Table 2. Selected characteristics of the two soils (means \pm standard errors).

\begin{tabular}{lcc}
\hline Property & Spodosol & Oxisol \\
\hline Total C $\left(\mathrm{g} \mathrm{kg}^{-1}\right)$ & $6.1 \pm 0.04$ & $13 \pm 0.05$ \\
$\mathrm{pH}\left(1: 5 \mathrm{water}_{(\mathrm{w} / \mathrm{v})}\right)$ & $4.9 \pm 0.1$ & $5.0 \pm 0.1$ \\
Bulk density $\left(\mathrm{Mg} \mathrm{m}^{-3}\right)$ & $1.6 \pm 0.1$ & $0.9 \pm 0.1$ \\
Clay $\left(\mathrm{g} \mathrm{kg}^{-1}\right)$ & $48 \pm 3$ & $499 \pm 38$ \\
Silt $\left(\mathrm{g} \mathrm{kg}^{-1}\right)$ & $37 \pm 1$ & $145 \pm 9$ \\
Sand $\left(\mathrm{g} \mathrm{kg}^{-1}\right)$ & $915 \pm 21$ & $356 \pm 19$ \\
Porosity $\left(\mathrm{m}^{3} \mathrm{~m}^{-3}\right)$ & $0.41 \pm 0.01$ & $0.67 \pm 0.08$ \\
Field capacity $\left(\mathrm{m}^{3} \mathrm{~m}^{-3}\right)$ & $0.07 \pm 0.02$ & $0.31 \pm 0.02$ \\
\hline
\end{tabular}

Oven-dried material was analyzed for total $\mathrm{N}$ (dry combustion method) and total $\mathrm{P}\left(\mathrm{HNO}_{3}+\mathrm{H}_{2} \mathrm{SO}_{4}\right.$ digestion followed by molybdate-vanadate color development) in order to determine the efficiency of each biosolid to supply ryegrass with $\mathrm{N}$ and phosphorus. Roots were collected after the last harvest, washed with deionized water, oven-dried $\left(70^{\circ} \mathrm{C}\right.$ for 72 hours) and also analyzed for total $\mathrm{N}$ and total $\mathrm{P}$, to help account plant $\mathrm{N}$ and $\mathrm{P}$ uptake from soils.

Nitrogen and $P$ taken by plants from control, fertilized and biosolids-treated soils at each harvest (dry matter yield $\times$ concentrations of nutrients in plant tissue) were summed for each treatment. Total amounts of $\mathrm{N}$ and $\mathrm{P}$ taken by plants from each treatment were divided by amounts of $\mathrm{N}$ and $\mathrm{P}$ supplied to soils from respective sources. Quotients were transformed in percentage as the representation of biosolids and fertilizers' efficiency to supply $\mathrm{N}$ and $\mathrm{P}$ to plants.

Data on total N, mineral N, total P and available P in soils were separately analyzed by soil type, due to their naturally large differences in nutrient concentrations. Data on cumulative yields and ryegrass internal $\mathrm{N}$ and P efficiency were analyzed together for both soils within each property as they have shown to be properly comparable. Analysis of variance and Tukey test were done in Minitab 12.1 for Windows.

\section{Results and Discussion}

Plant trial lasted eleven months and pots were harvested six times after a single application of either biosolids or chemical fertilizers to soils. There were considerable differences in mass of dry matter production among treatments at the first three harvests for both soils, after which yields were similar (Figures 1 and 2). Yield responses to chemical fertilization declined sharply from the first to the third harvest on the Oxisol while the second harvest produced the highest yields on all biosolids-amended Oxisol. Most likely, nutrient

Table 3. Total $\mathrm{N}$ and total $\mathrm{P}$ applied to air-dried soils, based on biosolids content.

\begin{tabular}{|c|c|c|c|c|c|}
\hline $\begin{array}{l}\text { Equivalent } \\
\text { dry } \mathrm{Mg} \mathrm{ha}^{-1}\end{array}$ & $\begin{array}{c}\text { Fresh } \\
\text { biosolids }\end{array}$ & $\begin{array}{c}\text { Composted } \\
\text { biosolids }\end{array}$ & $\begin{array}{c}30 \%-\mathrm{CaO} \\
\text { biosolids }\end{array}$ & $\begin{array}{c}250^{\circ} \mathrm{C} \text {-dried } \\
\text { biosolids }\end{array}$ & $\begin{array}{l}\text { Irradiated } \\
\text { biosolids }\end{array}$ \\
\hline & \multicolumn{5}{|c|}{$\mathrm{N}$ applied (mg $\mathrm{N} \mathrm{kg}^{-1}$ soil) } \\
\hline \multirow[t]{2}{*}{1.0} & 32.6 & 8.0 & 20.1 & 32.4 & 32.7 \\
\hline & \multicolumn{5}{|c|}{$\mathrm{P}$ applied (mg $\mathrm{P} \mathrm{kg}^{-1}$ soil) } \\
\hline 1.0 & 36.1 & 12.1 & 25.3 & 36.3 & 36.3 \\
\hline
\end{tabular}


availability from biosolids was greatest during the first sixteen weeks as a result of organic matter mineralization, since differences in plant production are chiefly determined by nutrient availability when water, light and heat do not limit growth (White, 1997).

Differences in plant growth during the first three harvests resulted in significantly different cumulative yields, depending on biosolids and soil types (Figure 3). Fresh and 30\%-CaO biosolids were exceptions as they produced for each biosolid similar cumulative yields on the two contrasting soils. Soil type has not prevailed over the degree of stabilization and nutrient availability from these two biosolids. The higher potential of the Oxisol to yield dry matter relative to the Spodosol was shown by most treatments, especially after applying Oxisol with chemical fertilizers. Nascimento et al. (2004) also obtained higher yields of bean and corn using fertilizers than applying heavy loads of fresh sewage biosolids to Espodossolo and Argissolo soils (Embrapa, 1999).

Cumulative yields from treated-soils were not a function of the amounts of total $\mathrm{N}$ and $\mathrm{P}$, mineral $\mathrm{N}$ and available $\mathrm{P}$ applied to soils as biosolids, since significant relations $(\mathrm{p}=0.05)$ could not be drawn among these factors. Mass of dry matter production and biosolids' efficiency to supply $\mathrm{N}$ are related to their mineralization rates in soils, not to the contents of nutrients present in these materials (Barbarick \& Ippolito, 2000). Therefore, the degree of biosolids stabilization combined with the capacity of a given soil to breakdown organic matter would determine yields and biosolids' efficiency to supply nutrients to plants.

After six consecutive harvests, composted biosolids and chemical fertilization showed the highest values for $\mathrm{N}$ efficiency on the Spodosol despite their modest

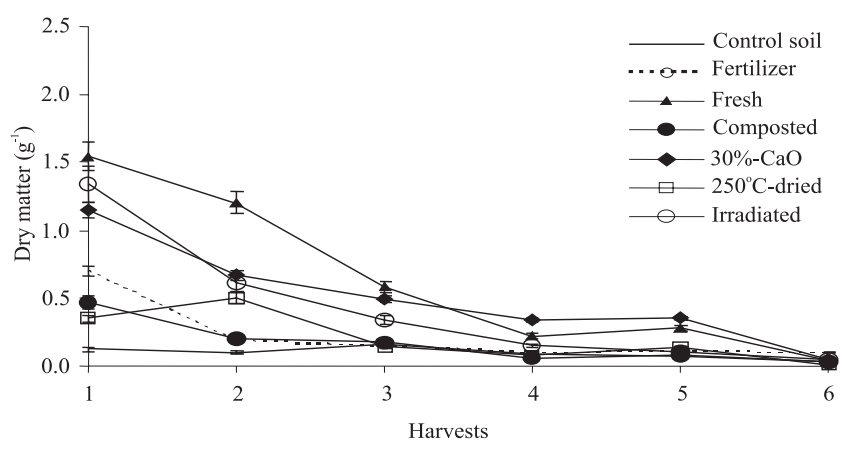

Figure 1. Ryegrass yields over six harvests on Spodosol (bars in each point represents means \pm standard error). cumulative yields. Approximately $36 \%$ of the $\mathrm{N}$ applied as composted biosolids were recovered in plant tissue, a similar proportion of $\mathrm{N}$ taken by ryegrass (38\%) from chemical $\mathrm{N}$ applied at $64 \mathrm{mg} \mathrm{kg}^{-1}$ soils. Plants grown with the other biosolids recovered $18 \%$ of the $\mathrm{N}$ applied as fresh, $30 \%-\mathrm{CaO}$, and solar-irradiated biosolids, and only $6 \%$ of the amount applied as $250^{\circ} \mathrm{C}$-dried biosolids. The highest proportion of $\mathrm{N}$ taken by plants, from composted biosolids, was from the material containing the lowest biosolids N (Table 1). Consequently, composted biosolids not only provided the greatest $\mathrm{N}$ efficiency but also left the lowest quantity of $\mathrm{N}$ in the Spodosol after six consecutive harvests. Villar et al. (1998) also reported higher plant $\mathrm{N}$ recovery by ryegrass from a soil amended with composted biosolids (24\% of the total $\mathrm{N}$ applied) than from fresh sewage biosolids $(17 \%)$.

Composts have lower $\mathrm{N}$ concentrations than their fresh feedstock and since efficiency for supplying nutrients is the ratio of plant nutrient uptake to supplied amount, small quantities of $\mathrm{N}$ taken by plants from composts result in significant proportions of $\mathrm{N}$ contained in these materials.

Low $\mathrm{N}$ efficiency for $250^{\circ} \mathrm{C}$-dried biosolids can be attributed to its low mineralization rate in Spodosol soil (Barbarick \& Ippolito, 2000). Effects of biosolids on plant growth depend largely on how quickly organic matter is mineralized to release nutrients (Cooper, 1996). The $250^{\circ} \mathrm{C}$-dried biosolids contains three times more total $\mathrm{P}$ and four times more total $\mathrm{N}$ than composted biosolids (Table 1), but they similarly produced the lowest cumulative yields amongst the amended-Spodosol soils (Figure 3). Thus, the incorporation of $250^{\circ} \mathrm{C}$-dried biosolids in a soil with low potential for mineralizing organic matter

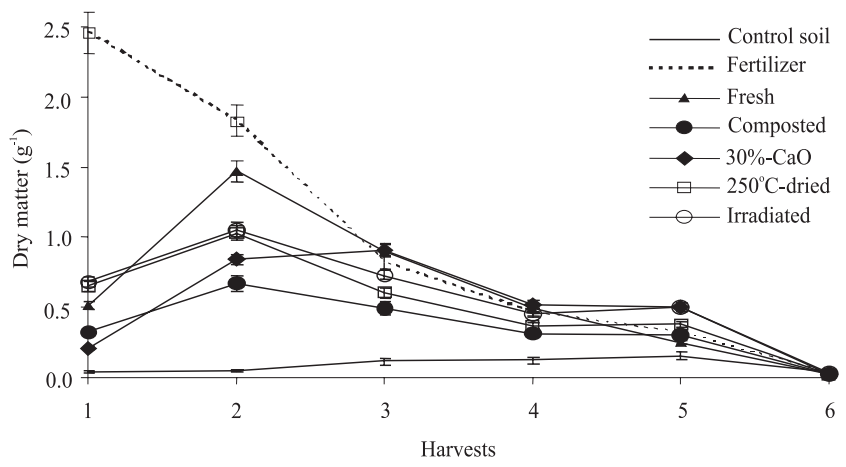

Figure 2. Ryegrass yields over six harvests on Oxisol (bars in each point represents means \pm standard error). 
resulted in approximately $94 \%$ of biosolids $\mathrm{N}$ not being utilized by ryegrass after six consecutive harvests over eleven months of trial (Figure 4).

Values for biosolids $\mathrm{N}$ efficiency were greater for the Oxisol than for the Spodosol soil. $\mathrm{N}$ is considered one of the main factors that boost plant development (Vaz \& Gonçalves, 2002). Higher biosolids mineralization in the Oxisol (Barbarick \& Ippolito, 2000) releases more $\mathrm{N}$ which results in higher yields (Figure 3 ) and consequently in a better use of biosolids $\mathrm{N}$ by plants (Figure 4). Ryegrass grown on this latter soil utilized approximately $75 \%$ of composted biosolids $\mathrm{N}$ and $53 \%$ of the $\mathrm{N}$ applied as $30 \%-\mathrm{CaO}$ biosolids. Fresh and solar-irradiated biosolids had $36 \%$ of their total $\mathrm{N}$ taken by ryegrass over six harvests while the $250^{\circ} \mathrm{C}$-dried biosolids restrained to $26 \%$. Plant $\mathrm{N}$ uptake from the Oxisol reached $115 \%$ of the chemical N, greater than all biosolids treatment, and showing native soil $\mathrm{N}$ was utilized as well. Nitrogen recovery in plants from chemically fertilized soils has been reported higher than from soils amended with biosolids. Sullivan et al. (1997) reported plant $\mathrm{N}$ recovered in grass from a loam soil was $65 \%-77 \%$ of the applied urea-N against $27 \%-38 \%$ applied as fresh sewage biosolids. Gavi et al. (1997) reported a plant $\mathrm{N}$ recovery of $17 \%$ and $27 \%$ from soils amended with fresh sewage biosolids and fertilized with $\mathrm{NH}_{4} \mathrm{NO}_{3}$, respectively. Greater uptake of $\mathrm{N}$ from fertilizers highlights the greater availability of chemical sources compared to biosolids.

Phosphorus from biosolids has been applied in excess at $\mathrm{N}$-agronomic rates (Pierzynski, 1994) because sewage materials have a much higher N:P ratio than required by plants (Mitchell et al., 2000). As a result,

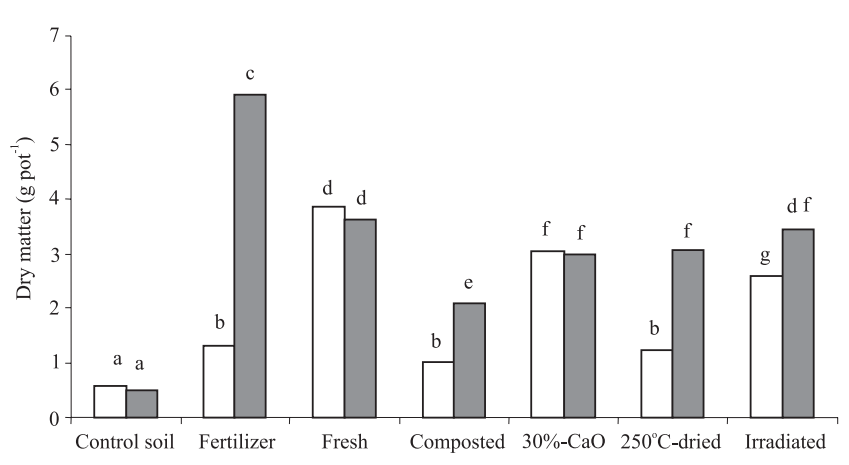

Figure 3. Cumulative yields on Spodosol ( $\square$ ) and Oxisol ( $\square$ ) for six harvests. Means with same letter are not statistically different by the Tukey test at $5 \%$ probability level. relative amounts of $\mathrm{P}$ taken by plants after six harvests were much lower than $\mathrm{N}$, and so were values for biosolids-P efficiency (Figure 4). Approximately $7 \%$ of the $\mathrm{P}$ applied as fresh, composted, $30 \%-\mathrm{CaO}$ and solarirradiated biosolids were recovered in ryegrass grown on the Spodosol versus 18\%-36\% N recovery. Plant P recovery from soil samples treated with $250^{\circ} \mathrm{C}$-dried biosolids was $3 \%$ of the amount applied versus $6 \%$ for N recovery. Vaz \& Gonçalves (2002) also report low biosolids P uptake by Eucalyptus grandis and partially attribute it to the low availability of $\mathrm{P}$ from biosolids.

The greatest biosolids $\mathrm{P}$ recovered from the Oxisol was measured for composted biosolids (3.7\%) applied at the rate of $12 \mathrm{mg} \mathrm{P} \mathrm{kg}^{-1}$ (Table 3). Meanwhile, 5.5\% of the $142 \mathrm{mg} \mathrm{P} \mathrm{kg}^{-1}$ applied as fertilizer to the Oxisol was taken by plants. Therefore, the efficiency of biosolids to supply $\mathrm{P}$ was at most $67 \%$ of the value measured for chemical $\mathrm{P}$ applied at a non-limiting rate. It is likely that low efficiency of biosolids as P sources on the Oxisol soil was partially caused by $P$ fixation instead solely by $\mathrm{N}: \mathrm{P}$ ratio required by plants. Biosolids are not pure sources of $\mathrm{N}$ and phosphorus. They contain a broad sort of chemicals and organic substances that alter soil's $\mathrm{pH}$, cation exchange capacity, organic $\mathrm{C}$, and other properties that may affect plant nutrient uptake (Oliveira et al., 2002).

Hence, Oxisols are high in free iron and clay content and the addition of aluminium sulphate during wastewater treatment works must have increased $\mathrm{P}$ fixation in this soil. Lu \& O'Connor (2001) demonstrated that P sorption by soils increased proportionally to biosolids application rates due to $\mathrm{Al}$ and $\mathrm{Fe}$ oxides contained in tertiary sewage biosolids $\left(10-14 \mathrm{~g} \mathrm{~kg}^{-1}\right)$. Except for the

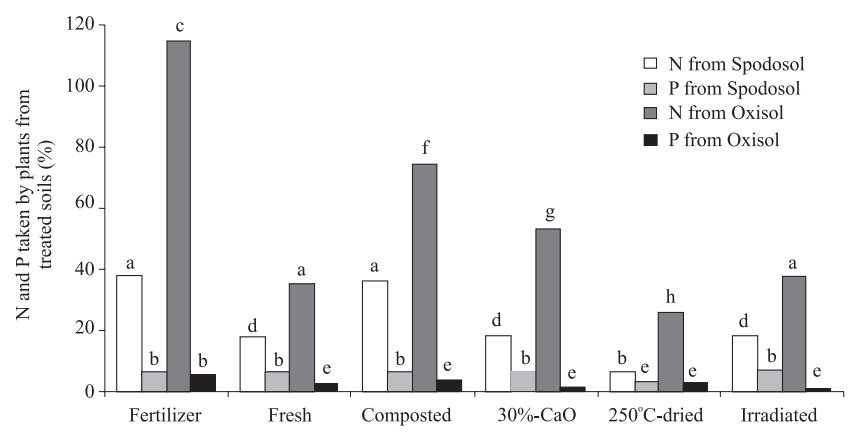

Figure 4. Percentages of $\mathrm{N}$ and $\mathrm{P}$ recovered in plant tissue, as compared to the amount applied, after six harvests from amended soils. Means with same letter are not statistically different by the Tukey test at 5\% probability level. 
Spodosol treated with $250^{\circ} \mathrm{C}$-dried biosolids, no significant differences $(p=0.05)$ were measured among the percentages of $\mathrm{P}$ from fertilizer and from biosolids recovered in plant tissue grown on the Spodosol (Figure 4); therefore, $\mathrm{P}$ fixing effects were unlike in the Spodosol.

No more than $7 \%$ of $\mathrm{P}$ and $36 \%$ of $\mathrm{N}$ applied as biosolids were utilized by ryegrass on the Spodosol over 11-month trial, similarly to the fertilized soil (Figure 4). Yields from amended Spodosol soil samples equaled to those from control soil with at least $93 \%$ of the $\mathrm{P}$ and $54 \%$ of the $\mathrm{N}$ applied being not utilized by plants. Biosolids $\mathrm{N}$ efficiency reached $75 \%$ of the amount applied to the Oxisol, but it was limited to $3.7 \%$ for phosphorus. Out of the $\mathrm{N}$ and $\mathrm{P}$ applied, $25 \%$ and $96 \%$ respectively remained in the Oxisol soil after six harvests.

The application of biosolids to soils at 1.0 dry $\mathrm{Mg} \mathrm{ha}^{-1}$ and the consecutive ryegrass clippings have not significantly changed total amounts of $\mathrm{N}$ and $\mathrm{P}$ in the treated soils relative to the respective control soils (Table 4). Nascimento et al. (2004) had to apply fresh sewage biosolids at a minimum 30 dry $\mathrm{Mg} \mathrm{ha}^{-1}$ rate to significantly increase total $\mathrm{N}$ and total $\mathrm{P}$ concentrations in soils.

However, mineral $\mathrm{N}$ and available $\mathrm{P}$ changed before and after plant experiment (Table 4). Concentrations of available $\mathrm{P}$ and mineral $\mathrm{N}$ increased soon after the application of biosolids and were significantly lower by the end of the plant trial. Silva et al. (2002) could also increase available $\mathrm{P}$ in a reddish Oxisol soil after applying freshly tertiary sewage sludge to it. But Nascimento et al. (2004) found the increment of available P in biosolidsamended soils is disproportionably lower when compared to application rates. Furthermore, an apparent antagonism between $\mathrm{P}$ and $\mathrm{Zn}$ in tissue of plants grown on soils amended with biosolids is mentioned by Vaz \& Gonçalves (2002) that might be related to soil $\mathrm{pH}$.

Table 4. $\mathrm{N}$ and $\mathrm{P}$ in soils before and after plant trial (means \pm standard errors) ${ }^{(1)}$.

\begin{tabular}{|c|c|c|c|c|c|c|}
\hline Parameter & $\begin{array}{l}\text { Control } \\
\text { soil }\end{array}$ & $\begin{array}{l}\text { Fresh } \\
\text { biosolids }\end{array}$ & $\begin{array}{l}\text { Composted } \\
\text { biosolids }\end{array}$ & $\begin{array}{l}30 \%-\mathrm{CaO} \\
\text { biosolids }\end{array}$ & $\begin{array}{l}250^{\circ} \mathrm{C} \text {-dried } \\
\text { biosolids }\end{array}$ & $\begin{array}{l}\text { Irradiated } \\
\text { biosolids }\end{array}$ \\
\hline & \multicolumn{6}{|c|}{ Spodosol soil } \\
\hline Before plant trial & $0.38 \mathrm{a}$ & $0.39 \mathrm{a}$ & $0.36 \mathrm{a}$ & $0.36 \mathrm{a}$ & $0.37 \mathrm{a}$ & $0.36 \mathrm{a}$ \\
\hline After plant trial & $0.37 \mathrm{a}$ & $0.37 \mathrm{a}$ & $0.36 \mathrm{a}$ & $0.36 \mathrm{a}$ & $0.37 \mathrm{a}$ & $0.36 \mathrm{a}$ \\
\hline \multirow[t]{2}{*}{$\begin{array}{l}\text { Before plant trial } \\
\text { After plant trial }\end{array}$} & $\begin{array}{l}0.11 \mathrm{a} \\
0.09 \mathrm{a}\end{array}$ & $\begin{array}{l}1.11 \mathrm{~b} \\
0.23 \mathrm{ae}\end{array}$ & $\begin{array}{l}\text { Miner } \\
0.63 \mathrm{c} \\
0.13 \mathrm{a}\end{array}$ & 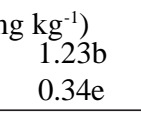 & $\begin{array}{l}0.82 \mathrm{c} \\
0.14 \mathrm{a}\end{array}$ & $\begin{array}{l}1.18 \mathrm{~b} \\
0.15 \mathrm{a}\end{array}$ \\
\hline & \multicolumn{6}{|c|}{ Total P $\left(\mathrm{g} \mathrm{kg}^{-1}\right)$} \\
\hline Before plant trial & $0.15 \mathrm{a}$ & $0.14 \mathrm{a}$ & $0.12 \mathrm{a}$ & $0.13 \mathrm{a}$ & $0.14 \mathrm{a}$ & $0.15 \mathrm{a}$ \\
\hline \multirow[t]{2}{*}{ After plant trial } & $0.14 \mathrm{a}$ & $0.15 \mathrm{a}$ & $0.11 \mathrm{a}$ & $0.13 \mathrm{a}$ & $0.13 \mathrm{a}$ & $0.15 \mathrm{a}$ \\
\hline & \multicolumn{6}{|c|}{ Available $\mathrm{P}\left(\mathrm{mg} \mathrm{kg}^{-1}\right)$} \\
\hline Before plant trial & $4.5 \mathrm{a}$ & $8.1 \mathrm{~b}$ & $7.4 \mathrm{~b}$ & $9.3 b$ & $7.7 \mathrm{~b}$ & $10.9 \mathrm{c}$ \\
\hline \multirow[t]{2}{*}{ After plant trial } & $2.1 \mathrm{~d}$ & $2.4 \mathrm{~d}$ & $1.2 \mathrm{e}$ & $3.7 \mathrm{a}$ & $4.2 \mathrm{a}$ & $1.9 \mathrm{~d}$ \\
\hline & \multicolumn{6}{|c|}{$\begin{array}{c}\text { Oxisol soil } \\
\text { Total } \mathrm{N}\left(\mathrm{g} \mathrm{kg}^{-1}\right)\end{array}$} \\
\hline Before plant trial & $1.56 \mathrm{a}$ & $1.59 \mathrm{a}$ & $1.58 \mathrm{a}$ & $1.69 \mathrm{a}$ & $1.54 \mathrm{a}$ & $1.68 \mathrm{a}$ \\
\hline \multirow[t]{2}{*}{ After plant trial } & $1.58 \mathrm{a}$ & $1.59 \mathrm{a}$ & $1.58 \mathrm{a}$ & $1.61 \mathrm{a}$ & $1.54 \mathrm{a}$ & $1.55 \mathrm{a}$ \\
\hline & \multicolumn{6}{|c|}{ Mineral $\mathrm{N}\left(\mathrm{mg} \mathrm{kg}^{-1}\right)$} \\
\hline Before plant trial & $4.9 \mathrm{a}$ & $7.1 \mathrm{~b}$ & $5.3 \mathrm{a}$ & $6.1 \mathrm{c}$ & $5.0 \mathrm{a}$ & $5.2 \mathrm{a}$ \\
\hline \multirow[t]{2}{*}{ After plant trial } & $0.5 \mathrm{~d}$ & $1.9 \mathrm{e}$ & $0.8 \mathrm{~d}$ & $0.4 \mathrm{~d}$ & $2.5 \mathrm{e}$ & $1.1 \mathrm{f}$ \\
\hline & \multicolumn{6}{|c|}{ Total P $\left(\mathrm{g} \mathrm{kg}^{-1}\right)$} \\
\hline Before plant trial & $1.98 \mathrm{a}$ & $2.01 \mathrm{a}$ & $1.99 \mathrm{a}$ & $2.01 \mathrm{a}$ & $2.02 \mathrm{a}$ & $2.02 \mathrm{a}$ \\
\hline \multirow[t]{2}{*}{ After plant trial } & $1.98 \mathrm{a}$ & $1.98 \mathrm{a}$ & $1.95 \mathrm{a}$ & $2.01 \mathrm{a}$ & $2.01 \mathrm{a}$ & $2.02 \mathrm{a}$ \\
\hline & \multicolumn{6}{|c|}{ Available $\mathrm{P}\left(\mathrm{mg} \mathrm{kg}^{-1}\right)$} \\
\hline Before plant trial & $8.7 \mathrm{a}$ & $9.5 \mathrm{a}$ & $13.0 \mathrm{~b}$ & $9.2 \mathrm{a}$ & $13.9 \mathrm{~b}$ & $9.0 \mathrm{a}$ \\
\hline After plant trial & $1.2 \mathrm{c}$ & $0.6 \mathrm{~d}$ & $0.4 \mathrm{~d}$ & $1.5 \mathrm{c}$ & $1.1 \mathrm{c}$ & $0.4 \mathrm{~d}$ \\
\hline
\end{tabular}

${ }^{(1)}$ Means with same letter for each soil and property are not statistically different by the Tukey test at $5 \%$ probability level. 


\section{Conclusions}

1. Different biosolids present different capacities to supply $\mathrm{N}$ and $\mathrm{P}$ to plants.

2. Biosolids are far more efficient to supply $\mathrm{N}$ than phosphorus.

3. Biosolids' efficiency as $\mathrm{N}$ and P sources depends also on soil type.

4. From $93 \%$ to $97 \%$ of biosolids $\mathrm{P}$ remain in soils after $\mathrm{N}$ exhaustion.

5. Low biosolids' efficiency to supply $\mathrm{P}$ for plant growth needs further investigation.

\section{References}

BARBARICK, K.A.; IPPOLITO, J.A. Nitrogen fertiliser equivalency of sewage biosolids applied to dryland winter wheat. Journal of Environmental Quality, v.29, p.1345-1351, 2000.

BOLLAND, M.D.A. Comparative phosphorus requirements of five annual medics. Journal of Plant Nutrition, v.20, p.1029-1043, 1997.

CAMERON, K.C.; DI, H.J.; MCLAREN, R.G. Is the soil an appropriate dumping ground for our wastes? In: AUSTRALIAN AND NEW ZEALAND NATIONAL SOILS CONFERENCE, 1996. Melbourne. Plenary papers. Melbourne: University of Melbourne, 1996. p.31-53.

COOPER, J.L. The agronomic value of biosolids in cropping systems on acid soils in central NSW. Sydney: NSW Agriculture Organic Waste Recycling Unit and Sydney Water, 1996. 256p.

EMBRAPA. Centro Nacional de Pesquisa de Solos (Rio de Janeiro, RJ). Sistema brasileiro de classificação de solos. Brasília: Embrapa-SPI; Embrapa-CNPS, 1999. 412p.

FRANK, R. The use of biosolids from wastewater treatment plants in agriculture. Environmental Management and Health, v.9, p.165-169, 1998.

GAVI, F.; RAUN, W.R.; BASTA, N.T.; JOHNSON, G.V. Effect of sewage sludge and ammonium nitrate on wheat yield and soil profile inorganic nitrogen accumulation. Journal of Plant Nutrition, v.20, p.203-218, 1997.

HAVILAH, E.; RAWLINSON, L.V.; OSBORNE, G.J. Biosolid as nitrogen fertilizers in coastal NSW. Sydney: NSW Agriculture Organic Waste Recycling Unit and Sydney Water, 1996. p.55-61.

LU, P.; O'CONNOR, G.A. Biosolids effects on phosphorus retention and release in some sandy Florida soils. Journal of Environmental Quality, v.30, p.1059-1063, 2001.

MITCHELL, D.S., EDWARDS, A.C.; FERRIER, R.C. Changes in fluxes of $\mathrm{N}$ and $\mathrm{P}$ in water draining a stand of Scots pine treated with sewage sludge. Forest Ecology and Management, v.139, p.203$213,2000$.
NASCIMENTO, C.W.A.; BARROS, D.A.S.; MELO, E.E.C.; OLIVEIRA, A.B. Alterações químicas em solos e crescimento de milho e feijoeiro após aplicação de lodo de esgoto. Revista Brasileira de Ciência do Solo, v.28, p.385-392, 2004.

NOOMAN, H.J.; FÜLEKY, G. Evaluation of the potential availability of phosphorus by plant uptake. In: COOK, H.F.; LEE, H.C. (Ed.). Soil management in sustainable agriculture. London: University of London, 1995. p.240-242.

OBERLE, S.L.; KEENEY, D.R. Interactions of sewage sludge with soil-crop-water systems. In: WEL, C.E.C.; DOWDY, R.H. (Ed.). Sewage sludge: land utilization and the environment. Madison: Soil Science Society of America, 1994. p.17-20.

O'BRIEN, N.D. Nutritional physiology of Eucaliptus grandis and Pinus radiata irrigated with municipal effluent. 1998. 289p. Thesis (Ph.D.) - University of Melbourne, Melbourne.

OLIVEIRA, F.C.; MATIAZZO, M.E.; MARCIANO, C.R.; ROSSETO, R. Efeitos de aplicações sucessivas de lodo de esgoto em Oxisol Amarelo distrófico cultivado com cana-de-açúcar: carbono orgânico, condutividade elétrica, pH e CTC. Revista Brasileira de Ciência do Solo, v.26, p.505-519, 2002.

PIERZYNSKI, G.M. Plant nutrient aspects of sewage sludge. In: WEL, C.E.C.; DOWDY, R.H. (Ed.). Sewage sludge: land utilization and the environment. Madison: Soil Science Society of America, 1994. p.21-26.

SILVA, J.E.; RESCK, D.V.S.; SHARMA, R.D. Alternativa agronômica para o biossólido produzido no Distrito Federal: I. Efeito na produção de milho e adição de metais pesados em Oxisol no cerrado. Revista Brasileira de Ciência do Solo, v.26, p.487-495, 2002.

SULLIVAN, D.M.; FRANSEN, S.C.; COGGER, C.G.; BARY, A.I. Biosolids and dairy manure as nitrogen sources for prairiegrass on a poorly drained soil. Journal of Production Agriculture, v.10, p.589596, 1997.

UNITED STATES ENVIRONMENTAL PROTECTION AGENCY. A guide to the biosolids risk assessments for the EPA part 503 rule. Federal Register, 58:9387-9415. Washington: Office of Wastewater Management, 1995. 143p.

VAZ, L.M.S.; GONÇALVES, J.L.M. Uso de biossólidos em povoamento de eucalipto: efeito em atributos químicos do solo, no crescimento e na absorção de nutrientes. Revista Brasileira de Ciência do Solo, v.26, p.747-758, 2002.

VILLAR, M.C.; GONZÁLEZ-PRIETO, S.J.; CARBALLAS, T. Evaluation of three organic wastes for reclaiming burnt soils: improvement in the recovery of vegetation cover and soil fertility in pot experiments. Biology and Fertility of Soils, v.26, p.122-129, 1998.

WHITE, R.E. Principles and practices of soil science: the soil as a natural resource. $3^{\text {rd }}$ ed. Victoria: Blackwell Science, 1997. 348p.

Received on April 23, 2004 and accepted on September 15, 2004 